\title{
Meiofauna responses to an experimental oil spill in a Louisiana salt marsh
}

\author{
J. W. Fleeger and G. T. Chandler \\ Department of Zoology and Physiology, Louisiana State University, Baton Rouge, Louisiana 70803, USA
}

\begin{abstract}
To determine the potential impact of an oil spill on Louisiana salt marsh meiofauna, $21 \mathrm{~m}^{-2}$ South Louisiana crude oil was applied to 4 randomly assigned experimental plots in a Spartina alterniflora marsh. Four unoiled plots served as controls. All plots were sampled 1 to $3 \mathrm{~h}$ before and on Days 2, 5, 10, 20, 30, 60, 95 and 144 following oil application. Meiofauna were sorted to major taxon, and copepods identified to species. Surprisingly, these meiofauna were highly tolerant of hydrocarbon stress as no oil-induced mortality could be identified in any taxon even though $>13000 \mu \mathrm{g} \mathrm{oil} \mathrm{g}^{-1}$ dry sediment was applied. Densities of several taxa did respond positively to oil application. Nematodes were significantly more numerous in oiled plots on Days 5 and 20; copepods on Days 30 and 60 . The increase in copepod numbers was due largely to a significant increase in Enhydrosoma woodini which reached densities of $18010 \mathrm{~cm}^{-2}$ in oiled plots. Copepods displayed only slight changes in community structure and no successional sequence was identified. Numbers of species were reduced somewhat on Days 5 to 10 as certain rare species were not encountered in oiled plots. Density increases most likely occurred because of increases in microbial production by oil-degrading bacteria, or because of oilinduced inhibition of predation. Additionally, a long-term effect may be present: copepod densities were significantly lower in oiled plots after $144 \mathrm{~d}$.
\end{abstract}

\section{INTRODUCTION}

Salt marshes are highly vulnerable to marine oil spills because of their low-energy intertidal position and high biotic productivity (Gundlach and Hayes, 1978; Sanders et al., 1980). Frequent oil transportation, pipeline and drilling operations near and in Louisiana marshes increase the probability of large and potentially harmful spills especially in oil-rich Southeast Louisiana. Unfortunately, most information on oil spill effects on marsh fauna have been gained in temperate settings (Sanders et al., 1980); only Lee et al. (1981) have studied oil impacts in a lower-latitude marsh. Meiofauna have not been investigated in relation to oil spills in salt marshes, except for the incidental collecting effort by Hampson and Moul (1978) who reported a decrease in meiofauna following a spill in a Massachusetts marsh.

Literature dealing with oil-spill effects on marine meiofauna is generally contradictory, and effects seem to be dependent on spill size and habitat characteristics as well as taxonomic grouping. In beaches and intertidal settings, nematodes appear to be relatively insensitive to all but very heavily oiled conditions (Boucher, 1980; Elmgren et al., 1980; Bonsdorf, 1981;
Fricke et al., 1981); if affected at all, they seem to recover rapidly (Wormald, 1976; Giere, 1979). Copepods have been reported to be severely impacted by some spills (Boucher, 1980; Bonsdorf, 1981; Fricke et al. 1981), and to recover more slowly than nematodes (Wormald, 1976). Naidu et al. (1978), however, report an increase in copepod density in experimentally oiled sites in an Alaskan mudflat. Unfortunately, replication and collection times in these field studies have been generally limited, e.g. Boucher (1980) took only 6 cores from March to October 1978.

In an effort to determine the potential impact of an oil spill on Louisiana salt marsh meiofauna, we experimentally oiled sediment plots. Plots and samples were replicated, and collections were made on 9 occasions to quantify effects adequately. We report here on oil impacts on meiofauna densities, and copepod species composition and relative abundance patterns.

\section{METHODS}

The study site was a Spartina alterniflora salt marsh located in LaFourche Parish, Louisiana (USA), specifically in the Wisner Wildlife Refuge $\left(29^{\circ} 15^{\prime} \mathrm{N}\right.$, 
$\left.90^{\circ} 15^{\prime} \mathrm{W}\right)$. The site, apparently undisturbed by petroleum activities, had a dense ground cover of 40 to $60 \mathrm{~cm}$ high S. alterniflora, and was located 4 to $10 \mathrm{~m}$ inland adjacent to a meandering bayou. Salinities in the bayou ranged from 20 to $28 \% \mathrm{~S}$, temperature from 28 to $33^{\circ} \mathrm{C}$. Sediments were largely silt-clays with sands comprising only $12 \%$ of sediment particles. For a general description of Louisiana marshes see Day et al. (1973).

Eight plots ( 2.65 by $2.65 \mathrm{~m}$ ) were randomly located in the streamside levee and surrounded by $30 \mathrm{~cm}$ high plywood frames. Plots were about $5 \mathrm{~m}$ apart, and 4 were randomly assigned as unoiled controls. During low tide on June 9, 1981 (Day 0), approximately $21 \mathrm{~m}^{-2}$ of South Louisiana crude oil (supplied by the American Petroleum Institute) was sprayed onto the marsh surface of 4 remaining plots with a garden sprayer. A layer of oil $2 \mathrm{~cm}$ deep was present initially; it remained visible for several months after oil introduction although it gradually worked downward until buried several $\mathrm{cm}$ below the surface. No attempt was made to mix the oil with the sediment. Two sides of the wooden frames were removed on Day 1 to allow free tidal flow through the plots. Oiled and control plots were intermixed so that variation along the streamside marsh could be determined.

Meiofauna samples (4 replicates from each plot) were taken from all plots 1 to $3 \mathrm{~h}$ prior to oil addition (Day 0), and then again on Days 2, 5, 10, 20, 30, 60, 95 and 144 following oil application. Samples were taken with $2.54 \mathrm{~cm}$ diameter plastic cores (modified $50 \mathrm{~cm}^{3}$ syringes) to a depth greater than $4 \mathrm{~cm}$, and then frozen in liquid nitrogen seconds after removal.

In the laboratory, cores were sectioned to $4 \mathrm{~cm}$ with a coping saw, and mixed in a $10 \%$ formalin-Rose Bengal solution. Samples were extracted with Ludox AM by centrifugation. Sediments were spun first to remove excess water (1300 rpm for $2 \mathrm{~min}$ ). Ludox AM was then added and the sediment was centrifuged at $975 \mathrm{rpm}$ for $3 \mathrm{~min}$. The supernatant was rinsed through a $63 \mu \mathrm{m}$ sieve and retained. Ludox was reintroduced into the centrifuge tube and a second centrifugation was performed. Supernatants and pellets were preserved in $10 \%$ formalin. The efficiency of Ludox AM extraction was measured by enumerating all fauna in pellets. After sorting approximately $10 \%$ of the pellets, efficiency averaged $92 \%$ for nematodes, and 96 to $98 \%$ for copepods. No further counts on pellets were made, and numbers reported are based on supernatant counts only. Meiofauna were enumerated to major taxon under a dissection microscope. All copepods, adults and copepodities, were identified to species.

Hydrocarbon levels in sediments were determined by fluorescence analysis of samples collected $2 \mathrm{~d}$ after oil introduction. Sediment was collected with $4 \mathrm{~cm}$ diameter core tubes, taken to a depth of $5 \mathrm{~cm}$. Sediment sub-samples $(100 \mathrm{ml})$ were homogenized in $150 \mathrm{ml}$ water, and extracted on a wrist shaker with $350 \mathrm{ml}$ of spectrograde hexane. Extracts were analysed with a fluorescence spectrophotometer. Samples were excited at $265 \mathrm{~nm}$ and scanned from 250 to $450 \mathrm{~nm}$. Peak intensities were measured at $365 \mathrm{~nm}$ and converted to $\mu \mathrm{g} \mathrm{g}^{-1}$ dry sediment using a South Louisiana crude oil sample as a standard, and reported as total aromatic hydrocarbons.

\section{RESULTS}

\section{Densities}

The meiofauna of the study site was dominated by nematodes and copepods. In control sediments, nematodes ranged from 154 to $76510 \mathrm{~cm}^{-2}$ and comprised $83 \%$ of the total meiofauna (Fig. 1). Copepods (Fig. 2) ranged from 35 to $10510 \mathrm{~cm}^{-2}$, comprising $10 \%$ of all fauna. Other abundant groups included polychaetes, oligochaetes and copepod nauplii. Several other groups, such as insect larvae and kinorhynchs, were occasionally encountered.

Seasonal changes were apparent in the species composition and relative abundances of the copepod assemblage. Nannopus palustris Brady was most abundant at the onset of the study, but declined to a fall low (Fig. 2). N. palustris reproduces only in spring (Coull et al., 1979; Fleeger, 1980), and would be expected to decline into the later summer and fall. Only adult females were encountered during our study. Enhydrosoma woodini Thistle was reproductively active and the most abundant copepod species throughout the study, comprising $59 \%$ of all individuals. Other abundant copepods included Nitrocra lacustris (Schmankevitsch), Halicyclops coulli Herbst, Onychocamptus mohammed (Blanchard and Richard), and Diarthrodes aedigius (Brain). E. woodini, N. palustris and N. lacustris together comprised $84 \%$ of all copepod individuals. In all, 22 species were identified.

Considerable variation in density was found from collection to collection among most taxa (Fig. 1 and 2). Water currents and tides may be responsible. Palmer and Brandt (1981) have shown that intertidal copepod densities are related to tidal variation. Our samples were collected at various tidal stages because of the unpredictability of Louisiana's wind-driven tides.

Generally, the study site appears to be representative of Louisiana salt marshes. Faunistically, it is very similar to other reported marsh sites for meiofauna major taxon composition and density, as well as copepod species composition and seasonal trends (Fleeger et al., 1982). 


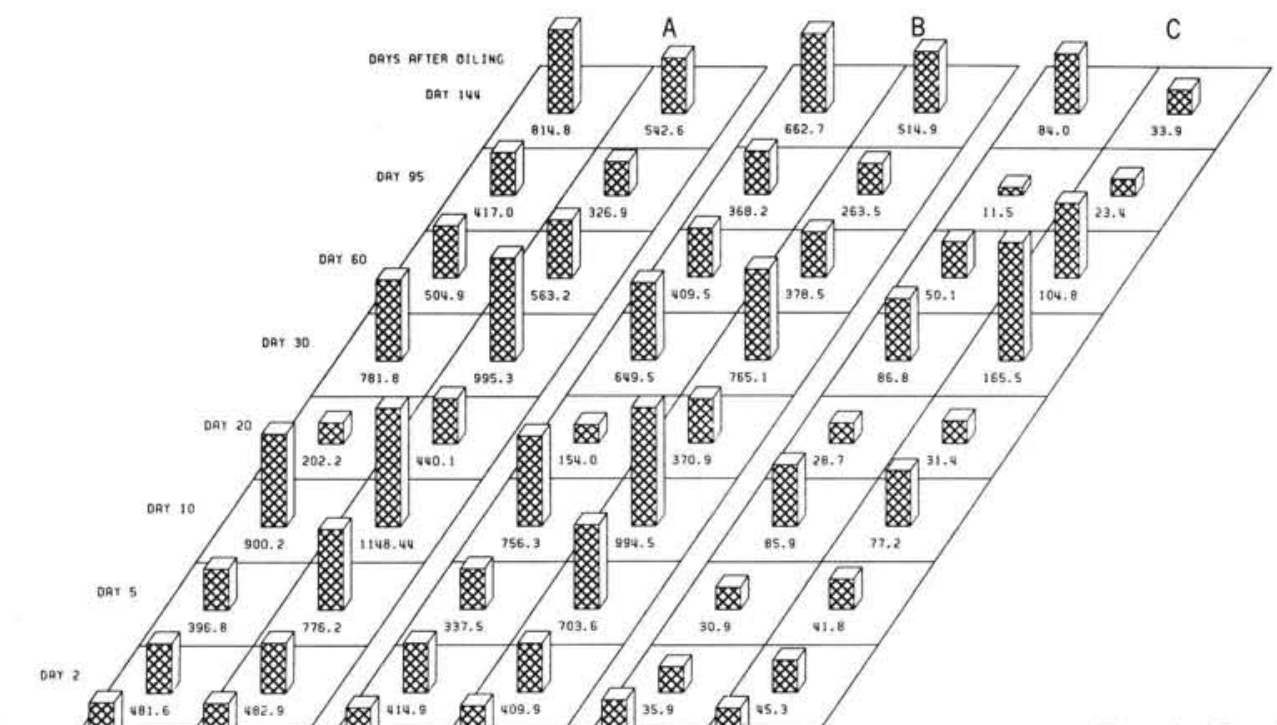

Fig. 1. Densities of total meiofauna (A), nematodes (B), and copepods (C) in oiled and control plots. Densities expressed in $10 \mathrm{~cm}^{-2}$

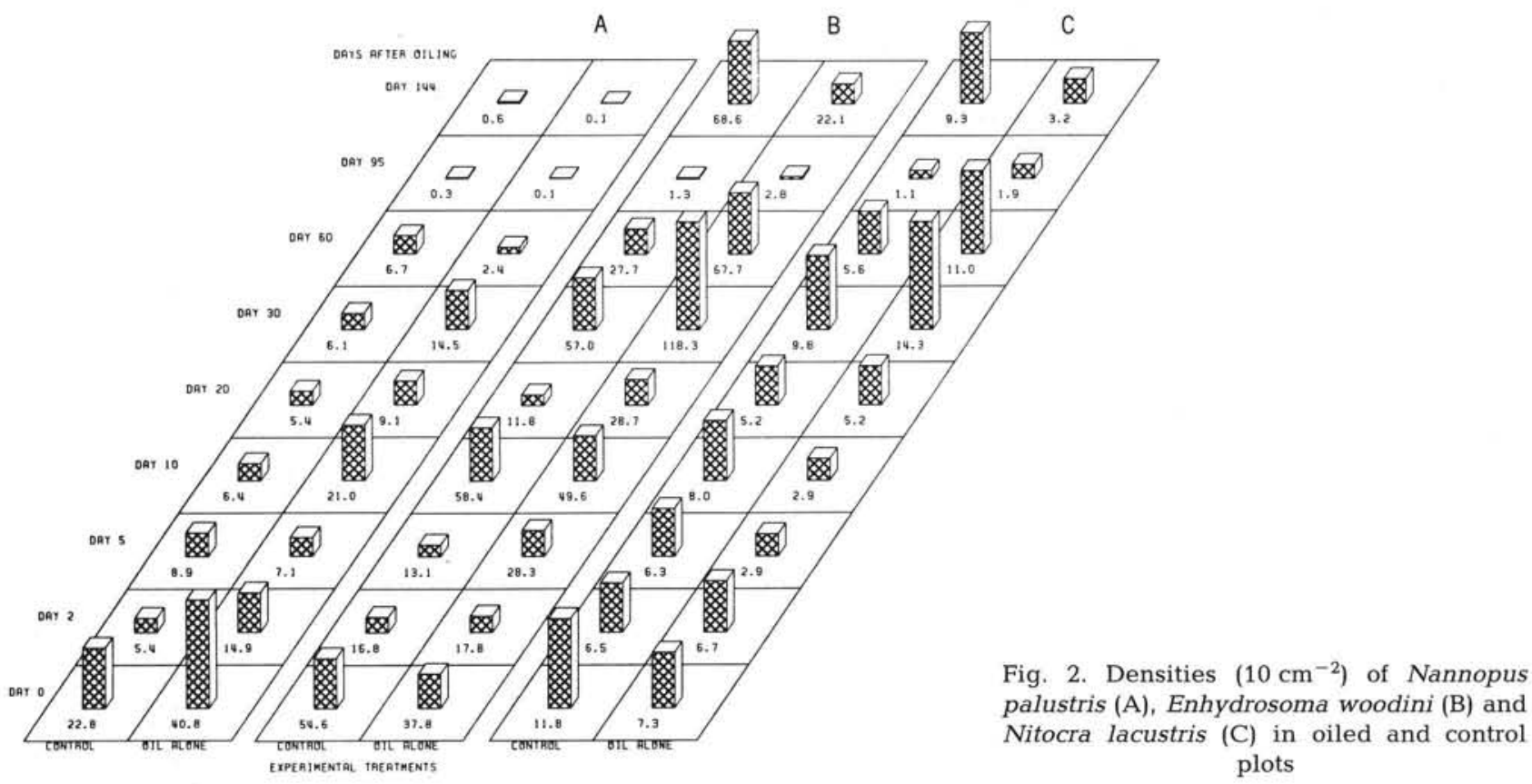

\section{Oil impacts on density}

Multiple analysis of variance (MANOVA) was conducted to test for significant variation in meiofauna densities among treatments (oiled and control sediments), among collection dates (Days 2 to 95) and among replicate plots. The results of these tests conducted on the densities of total meiofauna, nematodes, total copepods and the three most abundant copepod species, are summarized in Table 1. Variability was high; significant date variation was found for all taxa tested. Among-replicate-plot variability was generally low. Only Nannopus palustris exhibited significant variability among plots, indicating that plots on a given collection date were relatively homogeneous for meiofauna density. $N$. palustris displayed a highly aggregated distributional pattern which may be related to its declining population density. Significant effects due to the oiling treatment were found for all taxa tested except Nitocra lacustris. Duncan's multiple range test showed that in all cases where MANOVA was significant, densities were greater in the oiled 
Table 1. Summary of MANOVA statistics conducted to determine meiofauna density differences among treatments, dates and replicate plots. Treatment refers to control vs. oiled sediments. Values presented are probabilities

\begin{tabular}{|c|c|c|c|c|c|c|}
\hline & $\begin{array}{c}\text { Total } \\
\text { meiofauna }\end{array}$ & Nematoda & Copepoda & $\begin{array}{l}\text { Nannopus } \\
\text { palustris }\end{array}$ & $\begin{array}{l}\text { Enhydrosoma } \\
\text { woodini }\end{array}$ & $\begin{array}{l}\text { Nitrocra } \\
\text { lacustris }\end{array}$ \\
\hline Treatment: & 0.017 & 0.045 & 0.001 & 0.031 & 0.002 & 0.731 \\
\hline Date: & 0.001 & 0.001 & 0.001 & 0.012 & 0.001 & 0.001 \\
\hline Plot: & 0.394 & 0.505 & 0.205 & 0.018 & 0.636 & 0.298 \\
\hline Treatment by plot: & 0.431 & 0.262 & 0.009 & 0.115 & 0.021 & 0.077 \\
\hline
\end{tabular}

plots relative to controls (see also Figs. 1 and 2). In no instance did the oiling treatment reduce meiofauna densities, as would be expected if oil-induced mortality had occurred.

The time course for oil-stimulated increases in meiofauna density varied among taxa. One way ANOVA was conducted (where significant treatment effects in MANOVA were found) to compare densities in oiled and control plots on each collection date (plots were pooled because of the lack of significance among plots; Table 2). Total meiofauna and nematodes were significantly higher in oiled plots on Days 5 and 20 (averages were higher in oiled plots on Day 10; however, no significant differences were found). After Day 20 , densities for total meiofauna and nematodes were very similar in oiled and control plots. Total copepod densities were significantly higher in oiled plots on Days 30 and 60 only. Of the copepod species, only Enhydrosoma woodini showed significant increases in oiled plots. E. woodini densities in oiled plots were significantly greater on Day $30\left(\overline{\mathrm{x}}=5710 \mathrm{~cm}^{-2}\right.$ in controls compared to $11810 \mathrm{~cm}^{-2}$ in oiled plots; probability level $=0.045$ ) and Day $60 \overline{\mathrm{x}}=2810 \mathrm{~cm}^{-2}$ in controls compared to $6810 \mathrm{~cm}^{-2}$ in oiled plots; probability level $=0.061$ ). By Day 144, densities of total copepods and $E$. woodini were significantly lower in oiled compared to control plots indicating the possibility of a long-term negative oil impact on copepods.

\section{Oil impacts on community structure}

The copepod assemblage was analyzed to attempt to detect any oil-related changes in meiofauna community structure. Species diversity $\left(\mathrm{H}^{\prime}, \mathrm{J}^{\prime}\right.$ and number of species) values were calculated for each plot from each collection date, and an ordination was performed across all dates and treatments with the aid of computer programs by Bloom et al. (1977). The results of these tests indicate that several, fairly subtle oil-induced effects occurred. Species diversity values $\left(\mathrm{H}^{\prime}\right)$ were very similar in oil and control plots throughout the study with the exception of Days 5 to 20 when oiled plots showed lower diversity, and on Day 144 when oiled plots showed higher diversity (Fig. 3 ) relative to controls. Mann-Whitney U tests were conducted on each date to compare $\mathrm{H}^{\prime}$ in oiled and control plots; no significant difference was observed for any date, however. The number of species was quite similar in all plots on Days 0 and 2, but Days 5 to 20 showed fewer species in oiled plots. This reduction in species number took place among rare species as prominent

Table 2. Summary of one-way ANOVA statistics conducted on each date to compare meiofauna densities in oiled and control plots. The null hypothesis is no difference between densities in oiled and control plots. Values are probabilities

\begin{tabular}{|c|c|c|c|c|c|c|c|c|}
\hline \multirow[t]{2}{*}{ Taxon } & \multicolumn{8}{|c|}{ Days after oiling } \\
\hline & 2 & 5 & 10 & 20 & 30 & 60 & 95 & 144 \\
\hline Total meiofauna & 0.993 & $0.035^{\circ}$ & 0.223 & $0.024^{*}$ & 0.418 & 0.748 & 0.555 & 0.155 \\
\hline Nematoda & 0.969 & $0.025^{\circ}$ & 0.193 & $0.020^{*}$ & 0.614 & 0.841 & 0.489 & 0.413 \\
\hline Copepoda & 0.404 & 0.468 & 0.629 & 0.784 & $0.037^{\circ}$ & $0.021^{\circ}$ & 0.073 & $0.009^{*}$ \\
\hline Nanopus palustris & 0.062 & 0.662 & 0.194 & 0.458 & 0.084 & 0.183 & 0.300 & 0.149 \\
\hline Enhydrosoma woodini & 0.880 & 0.277 & 0.447 & 0.203 & $0.450^{\circ}$ & 0.061 & 0.241 & $0.010^{\cdots}$ \\
\hline
\end{tabular}




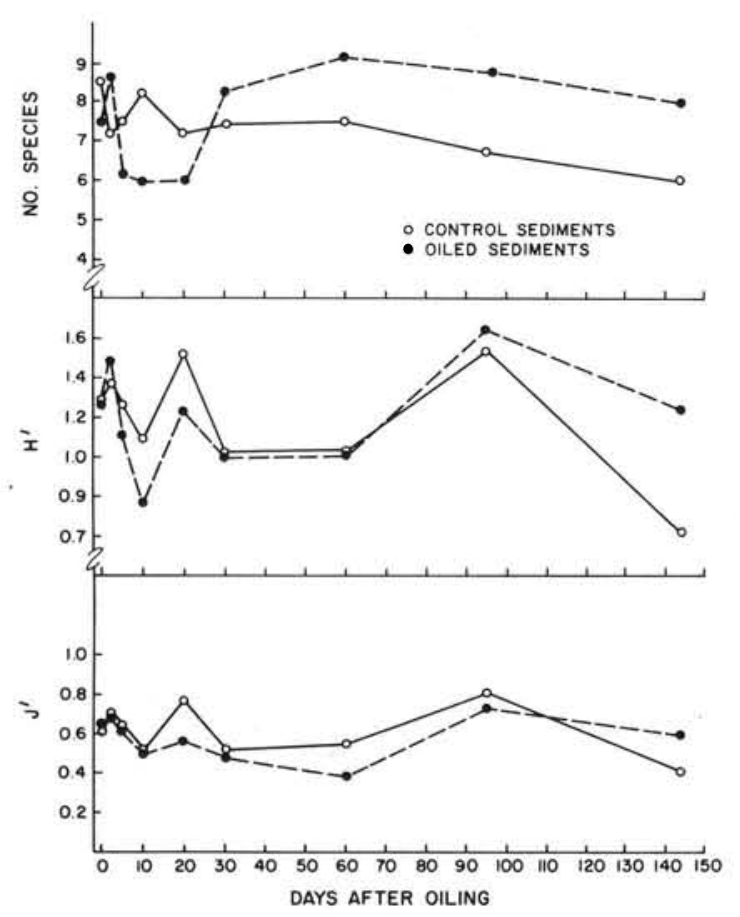

Fig. 3. Diversity values $\left(\mathrm{H}^{\prime}=\right.$ Shannon-Wiener; $\mathrm{J}^{\prime}=$ evenness; $\mathrm{s}=$ number of species) in oiled and control plots from each collection date

species were found in all plots. Again Mann-Whitney $\mathrm{U}$ tests would detect no significant differences among oiled and control plots on any given date. Evenness $\left(\mathrm{J}^{\prime}\right)$ varied little between oiled and control plots (Fig. 3).

Principal components ordination was used to relate all collections to each other on the same coordinate axes system (Fig. 4). Natural background variation among all plots appears to be slight as evidenced by similar locations of control and oiled plots on Days 0 and 2 (oil and control plots are located near each other on plots of Axis I vs. Axis II and Axis I vs. Axis III). Thus no oil effect could be identified until Day 5 following the oil introduction. Large separation of the oil and control plots took place on Days 5 and 10 indicating that the species composition and/or relative abundance patterns differed in response to the oiling. Species number was lower in oiled plots relative to controls on these collections (Fig. 2) suggesting that changes in community structure may be caused by a rapid loss of species in oil spill conditions. Three rare species - Stenhelia (D.) bifidia Coull, Pseudostenhelia wellsi Coull and Fleeger, and Leptocaris kunzi Fleeger and Clark - occurred in control plots on these days but did not occur in oiled plots. By Day 20, this initial oilinduced effect was not observed. Oiled and control plots were at nearly identical locations on Day 20 in the coordinate system indicating high similarities among oiled and control treatments. On subsequent collections oiled and control plots diverged somewhat. This divergence seems to be related more to changes in relative abundances than to species composition. $E$. woodini was the most abundant species; it showed significantly higher densities in oiled plots on Days 30 and 60, and significantly lower density on Day 144 . Thus a short-term, oil-induced effect (from Days 5 to 20 ) on community structure was seen through a reduction in species numbers, and a more long-range effect was characterized by increasing density (Days 30 to 95) finally followed by declining density by Day 144 .

\section{Hydrocarbon analysis}

Total hydrocarbons $2 \mathrm{~d}$ after oil application in unoiled control sediments ranged from 15 to $59 \mu \mathrm{g} \mathrm{g}^{-1}$ dry sediment with a mean of $44 \mu \mathrm{g}$. Levels in oiled sediments on the same day showed greater variability (possibly from differential tidal flushing or from the inability to apply oil in a perfectly uniform fashion), and ranged from 6736 to $20,384 \mu \mathrm{g} \mathrm{g}^{-1}$ dry sediment with a mean of $13,632 \mu \mathrm{g} \mathrm{g}^{-1}$ dry sediment. Despite greater hydrocarbon variability in oiled plots, the mean hydrocarbon level averaged 300 times the natural background concentration in control plots.
Fig. 4. Principal components ordination of the copepod assemblage in oiled and control plots on each collection date. Oiled and control plots on a given date are circled; numbers represent days after oiling. Open symbols: controls; closed symbols: oiled plots
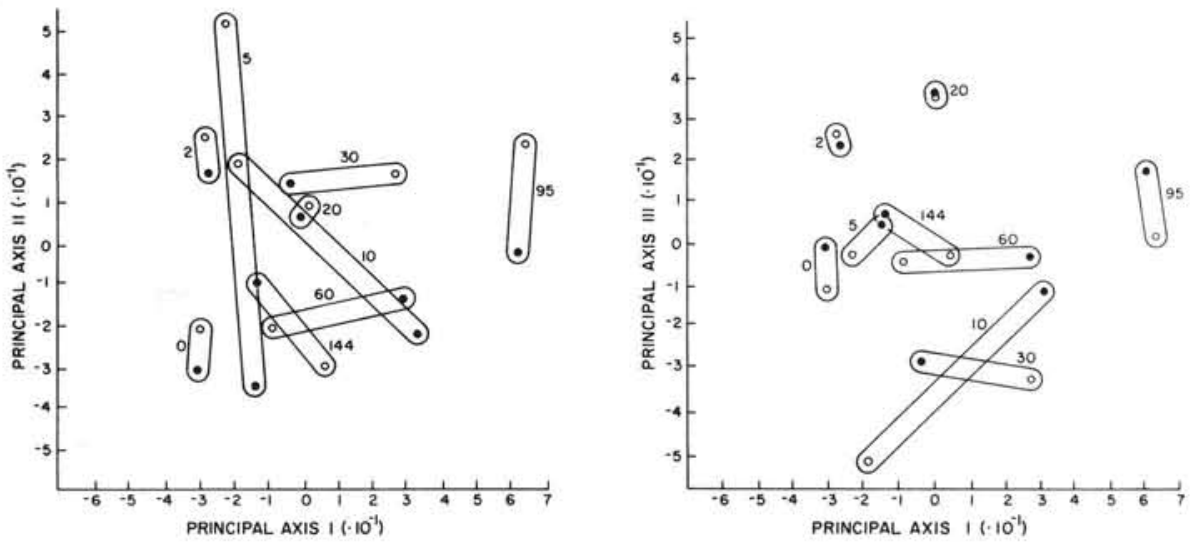


\section{DISCUSSION}

Experimental crude oil introduction did not cause any observable decline, relative to controls, in meiofauna densities of any taxonomic group investigated in this Louisiana salt marsh. In fact, oil apparently stimulated higher densities of nematodes and copepods, depending on the taxon, from 5 to $60 \mathrm{~d}$ after application. Thus no initial, oil-induced mortality could be detected.

The lack of meiofauna mortality in oiled sediments is surprising given the amount of oil applied $(\overline{\mathrm{x}}=$ $13000 \mu \mathrm{g} \mathrm{g}^{-1}$ ) and the usual field observation that heavy oil doses will rapidly decrease meiofauna densities, especially for copepods (Wormald, 1976; Giere, 1979; Boucher, 1980). Laboratory tolerance studies conducted on copepods show a contradictory picture of oil impacts, however. Some copepod species reveal greatly affected survivorship (Kontagiannis and Barnet, 1973), feeding (Berman and Heinle, 1980) and reproductive output (Ustach, 1979), while others show high tolerance to hydrocarbons (Dalla Venezia and Fossato, 1977). Refined oils are more toxic than crudes like the South Louisiana crude used in this experiment (Rossi et al., 1976; Carr and Reish, 1977); however, the amount of crude oil applied here would be expected to cause stress. For example, oil presence in the salt marsh is long lived. In a similar oiling experiment in the same marsh system, DeLaune et al. (1979) show that 60 to $70 \%$ of the oil applied was still present approximately $4 \mathrm{mo}$ after introduction. Furthermore, the ratios of alkanes to aromatics remained constant indicating that oil degrades slowly (DeLaune et al., 1979).

To survive these oiled conditions, Louisiana salt marsh meiofauna must have a high tolerance to hydrocarbon stress and low oxygen conditions accompanying the addition of an oil layer over sediments (DeLaune et al., 1979). Certainly, these animals live in an environment high in ambient stresses such as low $\mathrm{O}_{2}$ and variable salinities and temperatures (Vernberg and Coull, 1975), and perhaps they display a metabolic advantage in coping with new or novel stressors such as a sudden, large addition of hydrocarbons.

Increases in copepod densities 30 to $60 \mathrm{~d}$ after experimental oiling have been reported by Naidu et al. (1978). They suggest that such oil-induced meiofauna increases were due to increased bacterial production in oiled sediments, and subsequent heightened copepod grazing. Oil-degrading bacteria would be expected to show increased growth in oiled Louisiana sediments based on evidence from other salt marsh studies (Kator and Herwig, 1977; Lee et al., 1981), and thus would reasonably be expected to lead to the increased meiofauna densities reported in our study.
DeLaune et al. (1979) present evidence that oil application will not lead to increases in anaerobic bacterial activity in Louisiana marshes, but suggest that aerobic bacteria will be stimulated. Although no direct measure of microbial activities was made, redox values (DeLaune, pers. comm.) indicate that oxygen demand was greater in oiled plots, perhaps due to increased aerobic bacterial activity.

Other possible explanations exist for the increases in meiofauna abundance in oiled plots. Predation, either from swimming macrofauna (e.g. fish, shrimp) or from macroinfauna (e.g. fiddler crabs, annelids), could be impaired by the presence of oil thus bringing about a rise in density. Although experimental evidence does show that predators are hampered by oil (Fletcher et al., 1981), the role of predation in regulating salt marsh meiofauna is unclear. Evidence for predation by swimming macrofauna is conflicting. Bell and Coul (1978) and Bell (1980) used inclusion and exclusion studies to show that shrimp, fish etc. will decrease meiofauna densities in South Carolina marshes; however, Fleeger et al. (1982) report no effect of macrofauna exclusions on Louisiana marsh meiofauna. No studies have adequately investigated predation on salt marsh meiofauna by macro-infauna; however, oiling does not appear to reduce densities of these infauna. For example, Lee et al. (1981) found that fiddler crab densities were unaffected by oiling, and no statistically significant decreases in macro-infauna were observed in our investigation (pers. obs. based on ANOVA of a series of macrofauna samples). Evaluation of the likelihood that meiofauna densities increased because of lessening of predation must await clarification of the role of predation on marsh meiofauna. The fact that nematodes and copepods did not increase in abundance simultaneously would suggest that predation effects if present, are selective on the taxonomic grouping.

With the increasing awareness that meiofauna are relatively rapid sediment colonizers (Bell and Coen, 1982; Chandler and Fleeger, in press), selective immigration into oiled plots must be considered as a possible mechanism to account for meiofauna density increases. Colonization experiments into oiled, azoic sediment conducted by Alongi et al. (in press) show that complete colonization occurs in approximately $7 \mathrm{~d}$ for copepods and $16 \mathrm{~d}$ for nematodes and that no selective immigration into oiled sediments over unoiled sediments took place. There is no reason to doubt that immigration into the oiled plots occurred in this study, but we doubt that it occurred to the extent that densities would be elevated by immigration above ambient sediment densities. If immigration were significant to the density changes in oiled plots, copepods would be expected to change more rapidly than nematodes because they are faster colonizers (Chand- 
ler and Fleeger, in press). Increases in nematode abundance took place $25 \mathrm{~d}$ before increases in copepods.

Changes in copepod community structure occurred during the investigation (Fig. 4); however, these changes seem slight compared to oil effects on macrobenthic communities (Pearson and Rosenberg, 1978; Sanders et al., 1980). Copepod densities did not display a rapid response to oiling even though a slight decrease in the number of species took place. No successional sequence of species invasions occurred for copepods. Enhydrosoma woodini increases were not sudden or of an overwhelming dominance characteristic of opportunistic species. Nematodes may have undergone a successional change, however. Nematodes have already been shown to undergo successional changes in an oil polluted setting (Alongi et al., in press), and nematode densities did respond rapidly to oiling in Louisiana.

Generally, meiofauna would be expected to show rapid responses to oil pollution because of their dependence on the sediment and their short generation times. Rapid responses $(<2 \mathrm{mo})$ were quantified in this study; however, long-term effects on meiofauna are difficult to predict. Sanders et al. (1980) have shown long lasting effects of hydrocarbons on macrofauna communities, but several investigators have documented that meiofauna in the field appear to recover within $1 \mathrm{yr}$ afer an oil spill (Giere, 1979; Boucher, 1980). The possibility of a long-term oiling effect is seen in this investigation by a decrease of Enhydrosoma woodini densities in oiled sediments on Day 144. However, even longer collection times may prove necessary to evaluate the long-term effects of oil spills on meiofauna because of the long residence of oil within Louisiana salt marsh sediments.

Acknowledgements. We wish to thank W. Patrick and R. DeLaune for providing assistance in various aspects of field work and for conducting laboratory analyses of hydrocarbon levels. D. Boesch of the Louisiana Universities Marine Consortium (LUMCON) supplied the use of boats and laboratory facilities. C. Decker commented on an earlier manuscript draft, and Z. Manaf, S. Hilliard, B Hendricks and G. Fitzhugh were responsible for the bulk of sample sorting. Thanks to Yvette LeDoux for drafting figures. This project was funded by a grant from the American Petroleum Institute to W. Patrick and J.W.F.

\section{LITERATURE CITED}

Alongi, D. M., Boesch, D. F., Diaz, R. J. (in press). Colonization of meiobenthos in oil-contaminated subtidal sands in the Lower Chesapeake Bay, USA. Mar, Biol.

Bell, S. S. (1980). Meiofauna - macrofauna interactions in a high salt marsh habitat. Ecol. Monogr. 50: 487-505
Bell, S. S., Coen, L. D. (1982). Investigations on epibenthic meiofauna. I. Abundances on and repopulation of the tube-caps of Diopatra cuprea (Polychaeta: Onuphidae) in a subtropical system. Mar. Biol. 67: 303-309

Bell, S. S., Coull, B. C. (1978). Field evidence that shrimp predation regulates meiofauna. Oecologia (Berl.) 35: 141-148

Berman, M. S., Heinle, D. R. (1980). Modification of the feeding behavior of marine copepods by sublethal concentrations of water-accomodated fuel oil. Mar. Biol. 56: 59-64

Bloom, S. A., Santos, S. L., Field, J. G. (1977). A package of computer programs for benthic community analyses. Bull. mar. Sci. 27: 577-580

Bonsdorf, E. (1981). The Antonio Gramsci oil spill. Impact on the littoral and benthic ecosystems. Mar. Pollut. Bull. 12: 301-305

Boucher, G. (1980). Impact of Amoco Cadiz oil spill on intertidal and sublittoral meiofauna. Mar. Pollut. Bull. 11: 95-101

Carr, R. S., Reish, D. J. (1977). The effect of petroleum hydrocarbons on the survival and life history of polychaetous annelids. In: Wolfe, D. A. (ed.) Fate and effects of petroleum hydrocarbons in marine ecosystems and organisms. Pergamon Press, Oxford, p. 168-173

Chandler, G. T., Fleeger, J. W. (in press). Meiofaunal colonization of azoic estuarine sediment in Louisiana: mechanisms of dispersal. J. exp. mar. Biol. Ecol.

Coull, B. C., Bell, S. S., Savory, A. M., Dudley, B. W. (1979). Zonation of meiobenthic copepods in a southeastern United States salt marsh. Estuar. coast. mar. Sci. 9: 181-188

Dalla Venezia, L., Fossato, V. U. (1977). Characteristics of suspensions of Kuwait oil and Corexit 7664 and their short- and long-term effects on Tisbe bulbisetosa (Copepoda: Harpacticoida). Mar. Biol. 42: 233-237

Day, J. W., Smith, W. G., Wagner, P. R., Stowe, W. C. (1973). Community structure and carbon budget of salt marsh and shallow bay estuarine system in Louisiana. Center for Wetland Resources, Louisiana State University, B. R. Sea Grant Publ. No. LSU-SG-72-04

DeLaune, R. D., Patrick, W. H., Buresh, R. J. (1979). Effect of crude oil on a Louisiana Spartina alterniflora salt marsh. Environ. Pollut. 20: 21-31

Elmgren, R., Hansson, S., Larsson, U., Sundelin, B. (1980). Impact of deep soft bottoms. In: Kineman, J. J., Elmgren, R., Hansson, S. (eds.) The Tsesis oil spill. Report of the first year scientific study (October 1977 to December 1978). University Stockholm, Sweden

Fleeger, J. W. (1980). Community structure of an estuarine meiobenthic copepod assemblage. Estuar. coast. mar. Sci. 10: $107-118$

Fleeger, J. W., Whipple, S. A., Cook, L. L. (1982). Field manipulations of tidal flushing, light exposure and natant macrofauna in a Louisiana salt marsh: effects on the meiofauna. J. exp. mar. Biol. Ecol. 56: 87-100

Fletcher, G. L., Kiceniuk, J. W., Williams, U. P. (1981). Effects of oiled sediments on mortality, feeding and growth of winter flounder, Pseudopleuronectes americanus. Mar. Ecol. Prog. Ser. 4: 91-96

Fricke, A. H., Henning, H. F.-H. O., Orren, M. J. (1981). Relationship between oil pollution and psammolittoral meiofauna density of two South African beaches. Mar. environ. Res. 5: 59-77

Giere, O. (1979). The impact of oil pollution on intertidal meiofauna. Field studies after the La Coruna-spill, May 1976. Cah. Biol. mar. 20: 231-251 
Gundlach, E. R., Hayes, M. O. (1978). Vulnerability of coastal environments to oil spill impacts. Mar. Tech. Soc. J. 12: $18-27$

Hampson, G. R., Moul, E. T. (1978). No. 2 fuel oil spill on Bourne, Massachusettes: immediate assessment of the effects on marine invertebrates and a 3-year study of growth and recovery of a salt marsh. J. Fish. Res. Bd Can. 35: 731-744

Kator, H., Herwig, R. (1977). Microbial responses after two experimental oil spills on an eastern coastal plain estuarine ecosystem. In: Proceedings of the 1977 oil spill conference, American Petroleum Institute, Washington, D. C., p. $517-522$

Kontagiannis, J. E., Barnett, C. J. (1973). The effect of oil pollution on survival of the tidal pool copepod, Tigriopus californicus. Environ. Pollut, 4: 69-79

Lee, R. F., Dornseif, B., Gonsoulin, F., Tenore, K., Hanson, R. (1981). Fate and effects of a heavy oil spill on a Georgia salt marsh. Mar. environ. Res. 5: 125-143

Naidu, A. A., Feder, H. M., Norrell, S. A. (1978). The effect of Prudhoe Bay crude oil on a tidal-flat ecosystem in Port Valdez, Alaska. Tenth Offshore Technology Conference, Houston, Texas, p. 94-104

Palmer, M. A., Brandt, R. R. (1981). Tidal variation in sedi- ment densities of marine benthic copepods. Mar. Ecol. Prog. Ser. 4: 207-212

Pearson, T. H., Rosenberg, R. (1978). Macrobenthic succession in relation to organic enrichment and pollution of the marine environment. Oceanogr. mar. Biol. A. Rev. 16: 229-311

Rossi, S. S., Anderson, J. W., Ward, G. S. (1976). Toxicity of water-soluble fractions of four test oils for the Polychaetous annelids, Neanthes arenaceodentata and Capitella capitata. Environ. Pollut. 10: 9-18

Sanders, H. L., Grassle, J. F., Hampson, G. R., Morse, L. S., Garner-Price, S., Jones, C. C. (1980). Anatomy of an oil spill: long-term effects from the grounding of the barge Florida off West Falmouth, Massachusetts. J. mar. Res. 38: 265-380

Ustach, J. F. (1979). Effects of sublethal oil concentrations on the copepod Nitrocra affinis. Estuaries 2: 273-276

Vernberg, W. B., Coull, B. C. (1975). Multiple factor effects of environmental parameters on the physiology, ecology and distribution of some marine meiofauna. Cah. Biol. mar. 16: 721-732

Wormald, A. P. (1976). Effects of a spill of marine diesel oil on the meiofauna of a sandy beach at Picnic Bay, Hong Kong. Environ. Pollut. 11: 117-130 